\section{Effect of Herbal Extract on the Growth Performance, Serum Biochemical Composition, Ileal Histo-Morphology and Immune Response of Broiler Chickens}

\author{
Majed Rafeeq ${ }^{1, *}$, Nadeem Rashid ${ }^{1}$, Muhammad Masood Tariq ${ }^{1}$, Irfan Shahzad \\ Sheikh', Muhammad Zahid Mustafa ${ }^{1}$, Muhammad Shafee ${ }^{1}$, Khalid Mehmood ${ }^{1}$, \\ Rana Muhammad Bilal ${ }^{2}$ and Tauseef Asmat ${ }^{1}$ \\ ${ }^{1}$ Center for Advanced Studies in Vaccinology and Biotechnology (CASVAB), \\ University of Balochistan, Quetta, Pakistan \\ ${ }^{2}$ University College of Veterinary and Animal Sciences, The Islamia University of \\ Bahawalpur, Pakistan
}

\begin{abstract}
A B S T R A C T
The aim of this study was to evaluate the effects of ethanolic crude extracts of cumin (Cuminum cyminum) and jir (Artemisia scoparia) on the performance of broiler chickens. The study used 120 unsexed Hubbard one day old broiler chicks randomly divided into three groups of 40 chicks that were each further divided into four replicates of ten chicks. Extracts were introduced at $200 \mathrm{mg} / \mathrm{Kg}$ as feed supplement to two groups of broilers and the third group was kept as control (C) and offered a basal diet. The chicks were reared in floor pens bedded with saw dust litter. Measured feed was offered twice a day and drinking water was offered ad-libitum. Growth performance parameters, hematology, serum biochemistry, immune response (ND and SRBC), intestinal histo-morphology, bacterial enumeration and cecal volatile fatty acids (VFAs) were measured. There were significant improvements in weight gain (WG), feed conversion ratio (FCR) and average daily gain $(A D G)$ in the treatment groups supplemented with extract $(P<0.05)$ compared to control. Similarly, intestinal histo-morphic parameters and ileal bacterial count were significantly different between treatments $(\mathrm{P}<0.05)$, but no significant effect $(\mathrm{P}>0.05)$ was found on the cecal VFA content. Hematological and serum biochemical parameter values were significantly improved in extract groups compared to control $(\mathrm{P}<0.05)$. The antibody titer against Newcastle disease virus and sheep $\mathrm{RBC}$ showed no significant difference among treatment groups $(\mathrm{P}>0.05)$. Supplementation of herbal extracts as feed additives at $200 \mathrm{mg} / \mathrm{Kg}$ produced better growth performance of broiler chickens with no adverse effects.
\end{abstract}

\author{
Article Information \\ Received 05 May 2020 \\ Revised 29 June 2020 \\ Accepted 07 July 2020 \\ Available online 16 July 2021 \\ Authors' Contribution \\ MR conceived and performed \\ experiment and wrote the manuscript. \\ NR supervised the study. MMT \\ analysed the data and helped in \\ drafting. ISS performed serum \\ biochemical tests. MZM helped in \\ experiments and immune response \\ evaluation. MS helped in bacterial \\ enumeration. KM collected the \\ data. RMB sorted intestinal \\ histomorphology. TA helped in VFA \\ determination \\ Key words \\ Herbs, Extract, Broilers, Performance, \\ Histo-morphology, Bacterial \\ enumeration.
}

\section{INTRODUCTION}

$\mathrm{T}_{\mathrm{r}}$ he use of antibiotics as growth promoters plays a pivotal role in modern broiler chicken production (Sharifi et al., 2013). Antibiotic growth promoters (AGPs) exert antibacterial effects and thereby reduce bacterial load, improve lumen epithelium and decrease bacterial nutrients usage. The indirect effects of all these actions are translated into enhanced growth rate and better feed efficiency. However, recently reported antibiotic resistant bacterial strains may pose a major threat to public health. For this reason there is a concerted hunt for alternatives to antibiotics and different options have been investigated around the world (Mehrabi et al., 2012; Berrama et al., 2017). Medicinal plants and their products including

\footnotetext{
* Corresponding author: majid_casvab@yahoo.com 0030-9923/2021/0005-1793 \$ 9.00/0

Copyright 2021 Zoological Society of Pakistan
}

extracts and essential oils are potential alternatives that may be used in broiler production (Wati et al., 2015). Indeed, phytogenic additives are a good source of complex bioactive compounds such as flavonoids, coumarins, steroids, phenolics, purines, lipids and monoterpenoids (Brisibe et al., 2008). Many of these bioactive compounds can influence broiler production and health, and have various anti-oxidant, anti-inflammatory, immunomodulatory, anti-coccidiosis and anti-bacterial properties and can act as digestive tract modifiers.

Cuminum cyminum L. (cumin) is an aromatic spice, used to add flavour to food and serve as an appetite stimulant. Cumin is known to have antioxidant, carminative and anti-flatulent activity. It increases the motility of the gastro-intestinal tract, increases enzyme secretions and exerts antimicrobial effects (Chaudhry et al., 2012; Hajlaoui et al., 2010; Iacobellis et al., 2005). Important chemical constituents of cumin seeds include cuminaldehyde, pyrazines, carvone, limonene and linalool 
(Chaudhry et al., 2012).

Artemisia scoparia (Jir) grows wild or is cultivated in many parts of Asia and Europe. Compounds isolated from jir exhibit antibacterial, antioxidant and free radical scavenging activities (Yeung, 1985). Bioactive compounds found in jir include artemisia ketone, germacrene-D, verbenone, 1,8-cineole, eugenol, capillin and transpinocarveol.

Cumin and jir are well known ethno medicines and are used for gastrointestinal problems. Beside this their use in traditional folk medicine, availability and cost effectiveness was the criteria to select these herbs. Literature studies regarding the use of cumin extract as an additive in broiler chicken production exist, but to our knowledge there are no reports of using jir ethanolic extract as a growth promoter feed additive in broiler chicken production.

\section{MATERIALS AND METHODS}

The study used 120 unsexed Hubbard one day old broiler chicks randomly divided into three groups of 40 chicks that were each further divided into four replicates of ten chicks. Treatment groups were cumin (Cuminum cynimum) and jir (Artemisia scoparia), each supplemented with ethanolic crude extract at $200 \mathrm{mg} / \mathrm{kg}$ feed, and the control (C) group was offered a basal diet. Basal broiler feed (starter and finisher feeds) were formulated using ingredients available in the local market. Crude protein (CP) and metabolizeable energy (ME) were kept at $21 \%$ and $3000 \mathrm{kcal} / \mathrm{kg}$ in the starter diet and at $19 \%$ and 3100 $\mathrm{kcal} / \mathrm{kg}$ in the finisher diet, respectively.

\section{Extract preparation}

A sample of each selected herb $(500 \mathrm{~g})$ was cleaned by sieving to remove dust and undesirable particles. The herb was then rinsed with cold water and allowed to dry completely at $40^{\circ} \mathrm{C}$. Later the materials were coarsely ground (60-mesh size). For extraction, a $200 \mathrm{~g}$ pre-cleaned, dried and ground sample was placed in a glass vessel and absolute ethanol $(800 \mathrm{ml})$ was added. The mixtures were kept sealed for three days avoiding sunlight exposure, and mixed thrice daily by vigorous shaking. Thereafter, the mixtures were filtered through muslin cloth and the residues were again extracted twice with absolute ethanol to get all possible extractable components. An aliquot of extract $(250 \mathrm{ml})$ was subjected to rotary evaporation (Strike-Rotary evaporator, model \# 102/202 Steroglass S.R.L. Italy) at $40^{\circ} \mathrm{C}$ with 65 rotations per minute. After thorough evaporation of the ethanol, crude extracts were collected, weighed and stored at $4{ }^{\circ} \mathrm{C}$ in capped bottles.
Growth performance

All of the birds were weighed on a weekly basis prior to feeding in the morning. Weight gain (WG) and feed consumption (FC) of the replicates were recorded on a weekly basis and the feed conversion ratio (FCR), average daily gain (ADG), energy efficiency ratio (EER) and protein efficiency ratio (PER) were calculated.

\section{Hematology and serum biochemistry}

Hematology was carried out using a medionic cell counter whilst white blood cells (WBCs) were counted manually. A Micro Lab 300 Analyzer was used for serum biochemistry. Kits (Merck, France) were used following the manufacturer's instructions.

\section{Immune response}

The immune response of broiler chickens against Newcastle disease (ND) virus was evaluated using the haemagglutination inhibition (HI) technique previously adopted by Numan et al. (2005) with slight modifications to determine the antibody response. Briefly, a $50 \mu \mathrm{L}$ aliquot of serum containing antibody was serially diluted (twofold dilution) into a 96 -well U-bottomed micro-titer plate with phosphate buffered saline (PBS). The same volume of ND virus antigen was added and its haemagglutination activity was determined in terms of 4HA units. Antibody titers were recorded as the reciprocal of $\log _{2}$ of the highest serum dilution that inhibited agglutination of chicken red blood cells (RBCs) (indicated by button formation).

\section{Intestinal histo-morphology}

Intestinal (Ileal) histo-morphology was done by fixing intestinal tissue in wax and staining with Mayer hematoxylin-eosin (HE) stain. For morphological parameters, four intact and well-oriented villi were selected from the intestinal cross section of each slide prepared. Villus height was measured from the tip of the villus to the villus crypt junction, and villus width was also measured as the distance across the middle of each villus. Crypt depth was measured as the distance between the basement membrane and the mouth of the crypt. Morphological indices were determined using computer-aided light microscopy image analysis under 10x magnification of the objective lens (Chwen et al., 2013).

\section{Cecal volatile acid}

To determine volatile fatty acids (VFAs) the material within cecal tonsils $(n=5)$ were collected, pooled and stored at $-20^{\circ} \mathrm{C}$ in aliquots. Lactic acid, acetic acid and n-butyric acid were determined by HPLC equipped with a S1122 solvent delivery system and an S 3210UV-Visible detector (Syknm, Germany) adopting the methodology 
of Kliseviciute et al. (2014) with some modifications. An injection volume of $20 \mu \mathrm{L}$, wavelength $210 \mathrm{~nm}$ and flow rate of $0.8 \mathrm{ml} / \mathrm{min}$ were employed. The mobile phase was 80:20 $25 \mathrm{mM} \mathrm{KH} \mathrm{PO}_{4}(\mathrm{pH}$ 2.5): $\mathrm{MeOH}$. The cecal VFAs were determined using the following formula:

$$
\text { VFAs }(\text { assay } \%)=\frac{A_{t} \times W_{s} \times(100-W C \text { of standard })}{A_{s} \times W_{t} \times(100-W C \text { of sample })}
$$

Where, $A_{t}$ is peak area of sample, $A_{s}$ is peak area of standard solution, $\mathrm{W}_{\mathrm{s}}$ is weight of working standard, $\mathrm{W}_{\mathrm{t}}$ is weight of sample in $\mathrm{mg}$, and $\mathrm{WC}$ is percentage (\%) water content of the sample.

\section{Bacterial enumeration}

Digesta samples from the intestine (Ileum) for bacterial enumeration on day 42 were collected in a sterile container and mixed thoroughly. A representative sample $(1 \mathrm{~g})$ was serially diluted ten-fold in the physiological saline trypton. Each dilution was thoroughly mixed for 2 min. Petri plates containing Nutrient agar (OXOID) were used for total aerobe count; de Man, Rogosa and Sharpe (MRS) agar (OXOID) petri plates for lactobacillus spp. and Clostridium reinforced medium (RCM) for anaerobe bacterial count were used. The digesta were diluted up to $10^{-10}$ and used as inoculums in duplicate. The count made on countable plates was presented as the reciprocal $\log _{1 n} \mathrm{CFU} / \mathrm{g}$ digesta using the following formula: $\mathrm{CFU}$ (colony forming unit) $=\frac{\text { No. of colonies }}{\text { Vol. of culture plate } \times \text { Dilution factor }}$

Data were summarized using MS-excel and analyzed using one way analysis of variance and difference in means with the DMR test in SPSS-16 for windows. The statistical model used in the data analysis was:

$$
\mathrm{Y}_{\mathrm{ij}}=\mu+\mathrm{T}_{\mathrm{i}}+\mathrm{e}_{\mathrm{ij}}
$$

Where, $Y_{i j}$ is observation on the $j^{\text {th }}$ bird in the $i^{\text {th }}$ treatment, $\mu$ is overall mean, $T_{i}$ is effect of the $i^{\text {th }}$ treatment, and $e_{i j}$ is the random error term.

\section{RESULTS}

\section{Performance of broiler chickens}

The growth performance results of broiler chickens supplemented with herbal ethanolic extracts are given in Table I. The WG at the end of experiment (day 42) showed a significant difference $(\mathrm{P}<0.05)$ among treatment groups. Cumin extract as feed additive resulted in higher weight gain $(2218.3 \pm 7.65 \mathrm{~g})$ followed by jir $(2145.9 \pm 17.98 \mathrm{~g})$ in comparison to control $(2033.6 \pm 18.49 \mathrm{~g})$. FC of the treatment groups was significantly $(\mathrm{P}<0.05)$ different and highest FC was observed in the control group $(3929 \pm 17.60 \mathrm{~g})$, whilst least was in the cumin extract group $(3866 \pm 9.72 \mathrm{~g})$. Use of extract as feed additive improved FCR significantly $(\mathrm{P}<0.05)$ and a better FCR was observed for cumin $(1.74 \pm 0.09 \mathrm{~g} / \mathrm{g})$ whilst highest was in the control $(1.93 \pm 0.11 \mathrm{~g} / \mathrm{g})$. The ADG showed a significant difference $(\mathrm{P}<0.05)$ among treatment groups (Table I). The cumin extract group showed highest daily WG $(52.81 \pm 0.18 \mathrm{~g} / \mathrm{d})$ and lowest was in the control $(48.41 \pm 0.44 \mathrm{~g} / \mathrm{d})$. The EER and PER of the treatment groups showed significant difference among them $(\mathrm{P}<0.05)$. Cumin extract as additive showed the lowest EER and PER (535.98 $\pm 1.38 \mathrm{kcal}$ and $33.97 \pm 0.09 \mathrm{~g} / 100 \mathrm{~g}$ WG, respectively), whilst the control group consumed higher energy $(594.34 \pm 5.62 \mathrm{kcal} / 100 \mathrm{~g}$ $\mathrm{WG})$ and protein $(37.66 \pm 0.35 \mathrm{~g} / 100 \mathrm{~g} \mathrm{WG})$.

Table I.- Effect of herbal extracts on the broiler chicks performance on day 42 (Mean \pm SE).

\begin{tabular}{lccc}
\hline Parameters & Control & Cumin & Jir \\
\hline WG $(\mathrm{g})$ & $2033.6 \pm 18.49^{\mathrm{c}}$ & $2218.3 \pm 17.65^{\mathrm{a}}$ & $2145.9 \pm 17.98^{\mathrm{b}}$ \\
FC $(\mathrm{g})$ & $3929.0 \pm 25.11^{\mathrm{a}}$ & $3866.0 \pm 19.72^{\mathrm{b}}$ & $3908.1 \pm 16.61^{\mathrm{a}}$ \\
FCR $(\mathrm{g} / \mathrm{g})$ & $1.93 \pm 0.11^{\mathrm{a}}$ & $1.74 \pm 0.09^{\mathrm{b}}$ & $1.82 \pm 0.16^{\mathrm{b}}$ \\
ADG $(\mathrm{g} / \mathrm{d})$ & $48.41 \pm 0.44^{\mathrm{c}}$ & $52.81 \pm 0.28^{\mathrm{a}}$ & $51.09 \pm 0.18^{\mathrm{b}}$ \\
EER & $594.34 \pm 5.62^{\mathrm{a}}$ & $535.98 \pm 1.38^{\mathrm{b}}$ & $560.11 \pm 1.86^{\mathrm{b}}$ \\
PER & $37.66 \pm 0.35^{\mathrm{a}}$ & $33.97 \pm 0.9^{\mathrm{b}}$ & $35.49 \pm 0.12^{\mathrm{b}}$ \\
\hline
\end{tabular}

Cumin, Cuminum cyminum; Jir, Artemisia scoparia; WG, weight gain; FC, feed consumption; FCR, feed conversion ratio; ADG, average daily gain; EER, energy efficiency ratio (kcal/ $100 \mathrm{gBWG}$ ); PER, protein efficiency ratio $(\mathrm{g} / 100 \mathrm{gBWG})$. ${ }^{\mathrm{a}, \mathrm{b}} \mathrm{c}, \mathrm{d}$, different superscripts in the same column indicates significant difference $(\mathrm{P}<0.05)$.

Table II.- Effect of herbal extract on broiler chicks serum biochemical parameters on day 42 (Mean \pm SE).

\begin{tabular}{lccc}
\hline Parameters & Control & Cumin & Jir \\
\hline RBC $\left(1 \times 10^{6} \mu \mathrm{l}\right)$ & $2.92 \pm 0.047^{\mathrm{b}}$ & $3.20 \pm 0.04^{\mathrm{a}}$ & $3.15 \pm 0.064^{\mathrm{a}}$ \\
$\mathrm{WBC}\left(1 \times 10^{3} \mu \mathrm{l}\right)$ & $32.00 \pm 0.707^{\mathrm{a}}$ & $29.25 \pm 0.629^{\mathrm{b}}$ & $28.00 \pm 0.408^{\mathrm{b}}$ \\
$\mathrm{Hb}(\mathrm{g} / \mathrm{dl})$ & $9.27 \pm 0.16^{\mathrm{b}}$ & $10.68 \pm 0.41^{\mathrm{a}}$ & $10.22 \pm 0.40^{\mathrm{a}}$ \\
$\mathrm{TP}(\mathrm{g} / \mathrm{dl})$ & $3.45 \pm 0.07$ & $3.67 \pm 0.08$ & $3.63 \pm 0.11$ \\
Albumin $(\mathrm{g} / \mathrm{dl})$ & $1.63 \pm 0.105$ & $1.68 \pm 0.07$ & $1.57 \pm 0.09$ \\
Globulin (g/dl) & $1.81 \pm 0.154$ & $1.99 \pm 0.043$ & $2.06 \pm 0.140$ \\
Alb:Glob & $0.93 \pm 0.101$ & $0.84 \pm 0.04$ & $0.78 \pm 0.098$ \\
AST (IU/l) & $241.54 \pm 2.02^{\mathrm{a}}$ & $219.56 \pm 4.37^{\mathrm{b}}$ & $232.82 \pm 4.29^{\mathrm{a}}$ \\
ALT (IU/l) & $27.50 \pm 0.9$ & $25.18 \pm 0.8$ & $25.80 \pm 0.8$ \\
\hline
\end{tabular}

Cumin, CuminumCyminum; Jir, Artemisia scoparia; TP, total protein; Alb:Glob, Albumin : Globulin; AST, aspartate aminotransferase; ALT, alanin aminotransferase. a, b,c, different superscripts in the same row indicate significant difference $(\mathrm{P}<0.05)$.

\section{Broiler chicken hematology and serum biochemistry}

The results of blood cells count and serum biochemical parameters of the treatment groups at day 42 are given in Table II. The RBC counts show significant $(\mathrm{P}<0.05)$ differences between treatment groups. The highest $\mathrm{RBC}$ count was found in the cumin $(3.20 \pm 0.04)$ extract group, whilst the lowest count $(2.92 \pm 0.047)$ was in the control 
group. The WBC count was significantly $(\mathrm{P}<0.05)$ different among treatment groups. A higher WBC count was found in the control group (32.00 \pm 0.7$)$ and lowest was in the jir extract group (28.00 \pm 0.408$)$. The $\mathrm{Hb}$ of the broiler chicks at day 42 was significantly $(\mathrm{P}<0.05)$ different among treatments. No significant $(\mathrm{P}>0.05)$ differences were found in total serum protein, albumin, globulin or in the albumin:globulin ratio. The AST of the treatment groups showed significant $(\mathrm{P}<0.05)$ differences and highest AST was found in the control $(241.54 \pm 2.02)$ with a lower value in the cumin group (219.56 \pm 4.37$)$. No significant $(\mathrm{P}>0.05)$ differences were found in the ALT of treatment groups.

Table III.- Effect of herbal extract on the intestinal morphology indices $(\mathrm{mm})(\mathrm{Mean} \pm \mathrm{SE})$.

\begin{tabular}{lccc}
\hline Parameters & Control & Cumin & Jir \\
\hline Villus length & $1.52 \pm 0.069^{\mathrm{b}}$ & $1.69 \pm 0.035^{\mathrm{a}}$ & $1.62 \pm 0.045^{\mathrm{a}}$ \\
Crypt depth & $0.149 \pm 0.003^{\mathrm{a}}$ & $0.136 \pm 0.006^{\mathrm{b}}$ & $0.139 \pm 0.006^{\mathrm{b}}$ \\
Villus width & $0.159 \pm 0.010^{\mathrm{b}}$ & $0.168 \pm 0.018^{\mathrm{b}}$ & $0.175 \pm 0.017^{\mathrm{a}}$ \\
Muscularis & $0.265 \pm 0.012^{\mathrm{a}}$ & $0.193 \pm 0.011^{\mathrm{c}}$ & $0.207 \pm 0.015^{\mathrm{b}}$ \\
Surface area & $0.767 \pm 0.066^{\mathrm{b}}$ & $0.895 \pm 0.094^{\mathrm{a}}$ & $0.887 \pm 0.066^{\mathrm{a}}$ \\
\hline
\end{tabular}

Cumin, CuminumCyminum; Jir, Artemisia scoparia. a, b, c, different superscripts in the same row indicate significant difference $(\mathrm{P}<0.05)$.

\section{Broiler chicken ileal morphology}

The results of broiler chicken ileal histomorphological parameters are presented in Table III. Significant $(\mathrm{P}<0.05)$ differences in villi length were found among treatment groups. The longest villi were found in the cumin treated group $(1.69 \pm 0.035 \mathrm{~mm})$ and lowest was in control $(1.52 \pm 0.069 \mathrm{~mm})$. The crypt depth of the ileal sections had significant $(\mathrm{P}<0.05)$ differences among treatment groups. The largest crypt depth was found in the control group $(0.149 \pm 0.003 \mathrm{~mm})$ and the smallest was in the cumin group $(0.136 \pm 0.006 \mathrm{~mm})$. Villi widths were significantly different $(\mathrm{P}>0.05)$ between treatment groups. The largest villi widths were found in the jir treated group
$(0.175 \pm 0.017 \mathrm{~mm})$ whilst the smallest $(0.159 \pm 0.010 \mathrm{~mm})$ was in the control. The muscularis thickness of the ileum was significantly different $(\mathrm{P}<0.05)$ among treatment groups. The largest muscularis thickness was found in the cumin-treated group $(0.256 \pm 0.011 \mathrm{~mm})$ and the smallest was in the control $(0.185 \pm 0.012 \mathrm{~mm})$. The surface area of the villi also revealed significant differences among treatment groups and the largest villi surface area was found in the cumin-treated group $\left(0.895 \pm 0.094 \mathrm{~mm}^{2}\right)$ and the smallest was in the control group $\left(0.767 \pm 0.066 \mathrm{~mm}^{2}\right)$.

\section{Ileal bacterial enumeration}

The ileal bacterial counts of broiler chicks at day 42 are presented in Table IV. Total aerobe counts of the ileal digesta suggests a significant $(\mathrm{P}<0.05)$ difference among treatment groups. The highest aerobe count was found in the control group (7.75 \pm 0.62$)$ whilst the lowest $(6.25 \pm 0.47)$ was found in the cumin treated group. The coli form bacterial enumeration revealed a significantly $(\mathrm{P}<0.05)$ higher count in the control group. No significant $(\mathrm{P}>0.05)$ difference was found among the extract treated groups. Lactic acid bacterial counts were highest in the control group (6.62 \pm 0.12$)$ and lowest in the cumin group $(6.25 \pm 0.14)$. A significant $(\mathrm{P}<0.05)$ difference was found in the anaerobe count among treatment groups. The highest count was found in the control group (7.25 \pm 0.25$)$ and the lowest was in the cumin group $(6.0 \pm 0.35)$.

Table IV.- Effect of herbal extract on the ileal bacterial count on day 42 reciprocal of $\log _{10} \mathrm{CFU} / \mathrm{g}$ (Mean \pm SE).

\begin{tabular}{lccc}
\hline Parameters & Control & Cumin & Jir \\
\hline Aerobe & $5.75 \pm 0.62^{\mathrm{a}}$ & $4.25 \pm 0.47^{\mathrm{b}}$ & $4.50 \pm 0.28^{\mathrm{ab}}$ \\
Coli form & $6.12 \pm 0.23^{\mathrm{a}}$ & $5.00 \pm 0.20^{\mathrm{b}}$ & $5.12 \pm 0.42^{\mathrm{b}}$ \\
Lactic acid & $6.62 \pm 0.12^{\mathrm{a}}$ & $6.25 \pm 0.14^{\mathrm{ab}}$ & $5.50 \pm 0.20^{\mathrm{c}}$ \\
An-aerobe & $7.25 \pm 0.25^{\mathrm{a}}$ & $6.00 \pm 0.35^{\mathrm{b}}$ & $6.50 \pm 0.20^{\mathrm{ab}}$ \\
\hline
\end{tabular}

Cumin, CuminumCyminum; Jir, Artemisia scoparia. a, b, different superscripts in the same row indicate significant difference $(\mathrm{P}<0.05)$.
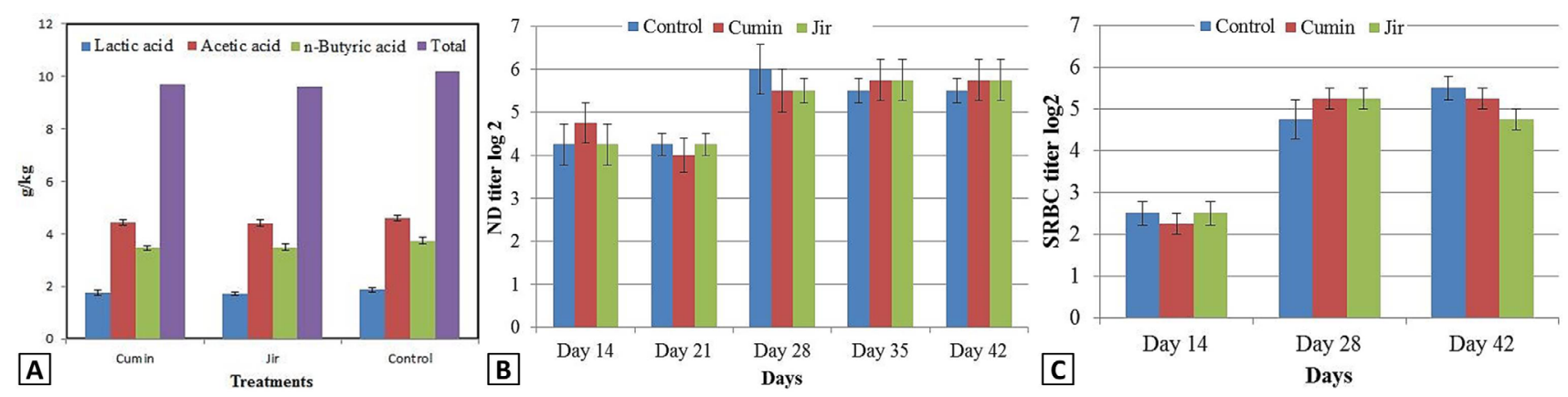

Fig. 1. Effect of herbal extract on broiler chicken cecal volatile fatty acids (A), ND titer $\left(\log _{2}\right)(B)$ and SRBC titer $\left(\log _{2}\right)(C)$ at day 42 . 


\section{Cecal volatile fatty acid}

The cecal VFA contents of broiler chicks at day 42 are presented in Figure 1A. The effects of herbal extracts on cecal lactic, acetic and butyric acid were found to be nonsignificant $(\mathrm{P}>0.05)$ between treatments.

\section{Immune response against $N D$ virus and sheep $R B C$}

The immune responses of the broiler chicks against ND virus on days 14, 21, 28, 35 and 42 and SRBC on days 14, 28 and 42 of treatment groups supplemented with herbal extracts are given in Figure $1 \mathrm{~B}$ and C. No significant differences in the titer among treatments and control were found $(\mathrm{P}>0.05)$.

\section{DISCUSSION}

In this study crude ethanolic extracts of two herbs were used as feed additives for broiler chickens. Significant improvements in growth performance parameters were found among herbal extract treatment groups as compared to control. Cumin extract produced the highest increase in WG (9.08\%) and FCR (9.84\%), whilst the group supplemented with jir extract showed higher WG (6.86\%) and better FCR (7.77\%) compared to control. The beneficial effects of herbs as feed additives observed in this study agree with previous reports (Elagib et al., 2012; El-Latif et al., 2013; Lukanov et al., 2015). Similarly, cumin seed extracts had been reported to enhance digestive enzymes activity, which ultimately leads to improved broiler chick performance (Milan et al., 2008). Such digestive stimulatory action of these spices may be through stimulation of indigenous digestive enzymes (Platel and Sirinivasan, 1996). Further improved growth performance in herbal extract groups could also be attributed to antibacterial activities, which result in reduction of ileal bacterial load and the availability of nutrients for bird growth (Mageed et al., 2012; Chaudhry et al., 2012).

The hematological parameters (RBC, WBC and $\mathrm{Hb}$ ) in this study showed significant differences among treatment groups. $\mathrm{RBC}$ count and $\mathrm{Hb}$ were higher in crude extract treatment groups, whilst WBC was higher in control. The findings are supported by Saha et al. (2013), who used organic soluble water additive and reported significantly higher values for RBC and $\mathrm{Hb}$. Similarly, a few other researchers (El-Latif et al., 2013; OleforuhOkoleh et al., 2015) used different phytogenic feed additives and reported increased $\mathrm{RBC}, \mathrm{Hb}$ and $\mathrm{PCV}$ values in broiler chickens. Changes in the components of blood could be used in interpreting the health condition of birds (Maxwell et al., 1990). In this study higher but within normal ranges of blood parameters suggests better health and immune status of the birds. However, an increased WBC count in the control cannot be explained because no visible abnormal symptoms were seen.

Serum biochemical indices of the treatment groups supplemented with herbal crude extracts showed no significant difference in serum total protein, albumin, globulin or in the albumin to globulin ratio. However, improvements have been seen in total protein and globulin parameters and this could be correlated to better health and immune status of the birds given herbal additives (Kapelenski et al., 2004). In previous studies with different herbal feed additives similar results have been reported (Venkatesh et al., 2002; Tollba et al., 2010; Bhaisare and Thyagarajan, 2014; Elagib et al., 2012). Liver enzyme AST revealed significant differences among treatment groups. Decreased liver enzymatic activities as a result of herbal supplementation are also reported (Ali et al., 2014; Sohail et al., 2012). The decreased liver enzyme activities in the present study suggest safety of the selected herbal extracts at the given dose.

In this study supplementation of broiler feed with herbal crude extract modified intestinal statues. Increased villi length, width, surface area and muscularis thickness of small intestine (Ileum) in comparison to control was evident. Many anatomical features determine the total absorptive surface area of the gastrointestinal tract (GIT). Villus height, width and number of villi per unit area all contribute to absorptive capacity (Miles et al., 2006). But, the morphological nomenclature of the intestine is not a constant entity and factors like nutrients (Yamauchi et al., 1996) and toxins (Awad et al., 2006) can change their features. The earlier reports by Abdullah et al. (2010) and Yasar et al. (2011) show increased villi length as a result of cumin and garlic supplement. The findings are in line with Garcia et al. (2007) and Ghazanfari et al. (2015) who suggested that herbal additive supplementation increased villi length. Longer intestinal villi and shorter crypt depth and increased surface area are considered as an indicator of a healthier gut, as it provides a greater area for nutrients absorption (Awad et al., 2009) and decreased cellular (enterocytes and goblet cells) turnover.

The metabolic activities of the bacteria produce VFAs which are liberated in the lower part of the intestine especially in the cecum. It is thought that bioactive compounds of the herbs enhance short chain VFA production in the lower part of the intestine (Flickinger et al., 2003). The cecal VFAs, i.e. acetic, lactic and butyric acids were found to be non-significant among treatment groups and the crude extracts did not reveal any significant effect on cecal VFAs. A numeric decrease in VFAs was found in extract treatment groups as compared to control. 
A decrease in n-butyric acid concentration in the cecal content suggests reduced clostridial activity (Wagner and Thomas, 1978). Similarly, decreased lactic acid concentration could be related to decreased activity of lactic acid producing bacteria (Manzanilla et al., 2004; Cross et al., 2011). In the present study supplementation of herbal extracts in the lower part of the intestine could be related to decrease bacterial proliferation, resulting in lower VFA concentration. This decreased VFA and bacterial activity can improve the availability and absorption of nutrients digested and improves feed utilization (Bedford and Cowieson, 2012).

The microbes inhabit every part of the gut and it is estimated that they consume 6 to $10 \%$ of the nutrients supplied in the feed. The bacterial population characteristics can be determined in all parts of the intestinal tract (Peinado et al., 2012; Jimoh et al., 2013). The illeal bacterial enumeration in the present study suggests that inclusion of herbal extract in the feed as growth promoter altered the gut micro flora population characteristics and significantly reduced total aerobe, coliform, lactic acid and anaerobe bacterial count. Present findings also correlate with cecal VFA concentration where a numeric decrease was found. The present findings are in line with Franciosini et al. (2016) and Walsh et al. (2003) who reported a reduction in bacterial activities in the presence of phytogenic additives. The mechanism behind alteration of the bacterial population could be the active compounds (cumin aldehyde, phenols, tannins and carvacrol in cumin, $\beta$-pinene and limonene in jir) present in the herb extracts that infuse into the bacterial cell and inhibit normal cellular activities (Abdel-Wareth et al., 2012; Helander et al., 1998). Alternatively, active components in the herbal supplements could have modified the gut environment decreasing the $\mathrm{pH}$ of the digesta, making the intestinal environment unfavorable for microbes, resulting in a decreased microbial population.

The immune response against ND virus and SRBC of broiler chickens were not significant among treatment groups, although numeric differences were present in the antibody titer of broiler chickens and a slight increase in titer was found among herbal extract treatment groups. The effect of phytogenic feed additive on broiler immunity has been reported with inconsistent results. Several researchers (Jafari et al., 2009; Pourali et al., 2010; Bozkurt et al., 2014) concluded no beneficial effect on humoral immune response when feed was supplemented herbal additives. On the other hand, El-Latif et al. (2013) and Gholamrezaie et al. (2013) reported positive effects of herbal additive supplementation and enhanced immunity. The differences in the results could be due to different experimental conditions and the type of additive used.

\section{CONCLUSION}

In this study supplementation of broilers with crude ethanolic extracts of cumin and jir as feed additives enhanced growth and improved feed efficiency. Hematological and serum biochemical parameters were found to be improved within normal ranges suggesting safety of extract at the given concentration. Extract supplementation improved morphological structure of the intestine and this in turn improved digestion and absorption of nutrients. The gut bacterial population was moderately modified and showed a reduction in CFU in the ileum at day 42 of the experiment. In general from the parameters observed in this study it can be concluded that crude extracts of the selected herbs improved growth performance.

\section{ACKNOWLEDGEMENT}

The authors acknowledge the CASVAB, University of Baluchistan for support.

Animal welfare statement

The authors confirm that the ethical policies of the journal, as noted on the journal's author guidelines page, have been adhered to and the appropriate ethical review committee approval has been received.

\section{Statement of conflict of interest}

The authors declare no conflict of interest in terms of financial or non-financial interest in the subject matter or materials discussed in this manuscript.

\section{REFERENCES}

Abdel-Wareth, A., Kehraus, S., Hippenstiel, F. and Südekum, K.H., 2012. Effects of thyme and oregano on growth performance of broilers from 4 to 42 days of age and on microbial counts in crop, small intestine and caecum of 42-day-old broilers. Anim. Feed Sci. Tech., 178: 198-202. https://doi. org/10.1016/j.anifeedsci.2012.10.006

Abdullah, A.Y., Mahmoud, K.Z., Nusairat, B.M. and Qudsieh, R.I., 2010. Small intestinal histology, production parameters, and meat quality as influenced by dietary supplementation of garlic (Allium sativum) in broiler chicks. Italian J. Anim. Sci., 9: 419-424. https://doi.org/10.4081/ijas.2010. e80

Ali, N., Shah, S.W.A., Ahmed, G., Shah, I., Shoaib, M., Junaid, M. and Ali, W., 2014. Acute toxicity and antispasmodic activities of Achillea wilhelmsii C. Koch. Pak. J. Pharm. Sci., 27: 309-315. 
Awad, W., Böhm, J., Razzazi-Fazeli, E., Ghareeb, K. and Zentek, J., 2006. Effect of addition of a probiotic microorganism to broiler diets contaminated with deoxynivalenol on performance and histological alterations of intestinal villi of broiler chickens. Poult. Sci., 85: 974-979. https://doi.org/10.1093/ $\mathrm{ps} / 85.6 .974$

Awad, W., Ghareeb, K., Abdel-Raheem, S. and Böhm, J., 2009. Effects of dietary inclusion of probiotic and synbiotic on growth performance, organ weights, and intestinal histomorphology of broiler chickens. Poult. Sci., 88: 49-56. https://doi.org/10.3382/ ps.2008-00244

Bedford, M., 2000. Removal of antibiotic growth promoters from poultry diets: Implications and strategies to minimise subsequent problems. World's Poult. Sci. J., 56: 347-365. https://doi. org/10.1079/WPS20000024

Bedford, M. and Cowieson, A., 2012. Exogenous enzymes and their effects on intestinal microbiology. Anim. Feed Sci. Tech., 173: 76-85. https://doi. org/10.1016/j.anifeedsci.2011.12.018

Berrama, Z., Temim, S., Souames, S. and Ainbaziz, H., 2017. Growth performance, carcass and viscera yields, blood constituents and thyroid hormone concentrations of chronic heat stressed broilers fed diets supplemented with cumin seeds (Cuminum cyminum L.). Kafkas Üniv. Vet. Fakül. Derg., 23: 735-742.

Bhaisare, D.B. and Thyagarajan, D., 2014. Effect of four herbal seeds on blood parameters in turkey poults. Int. J. Sci. Res., 3: 235-240.

Bozkurt, M., Aysul, N., Küçükyilmaz, K., Aypak, S., Ege, G., Catli, A.U., Akşit, H., Çöven, F., Seyrek, K. and Çinar, M., 2014. Efficacy of in-feed preparations of an anticoccidial, multienzyme, prebiotic, probiotic, and herbal essential oil mixture in healthy and Eimeria spp.-infected broilers. Poult. Sci., 93: 389399. https://doi.org/10.3382/ps.2013-03368

Brisibe, E.A., Umoren, U.E., Owai, P.U. and Brisibe, F., 2008. Dietary inclusion of dried Artemisia annua leaves for management of coccidiosis and growth enhancement in chickens. Afr. J. Biotech., 7: 40834092.

Chaudhry, A.H., Tanveer, A., Shar, A., Akhtar, M.S., Shahid, M.K., Ashfaq, K.M., Malik, T.A. and Siddiqui, R.H., 2012. Physico-chemical investigation and antimicrobial activity of essential oil of Cuminum cyminum L. World appl. Sci. J., 19: 330-333.

Chwen, L.T., Foo, H.L., Thanh, N.T. and Choe, D., 2013. Growth performance, plasma fatty acids, villous height and crypt depth of preweaning piglets fed with medium chain triacylglycerol. AsianAustralasian J. Anim. Sci., 26: 700-704. https://doi. org/10.5713/ajas.2012.12561

Cross, D. E., McDevitt, R. and Acamovic, T., 2011. Herbs, thyme essential oil and condensed tannin extracts as dietary supplements for broilers, and their effects on performance, digestibility, volatile fatty acids and organoleptic properties. Br. Poult. Sci., 52: 227-237. https://doi.org/10.1080/0007166 8.2011 .559454

Elagib, H., Nabiela, E., Abbass, S. and Ginawi, T., 2012. Effect of natural spices on plasma proteins in broiler chicks. J. Nutr. Fd. Sci., 2: 152-160.

El-Latif, A.S.A., Saleh, N.S., Allam, T.S. and Ghazy, E.W., 2013. The effects of rosemary (Rosemarinus afficinalis) and garlic (Allium sativum) essential oils on performance, hematological, biochemical and immunological parameters of broiler chickens. Br. J. Poult. Sci., 2: 16-24.

Flickinger, E.A., Loo, J.V. and Fahey, G.C., 2003. Nutritional responses to the presence of inulin and oligofructose in the diets of domesticated animals: A review. Crit. Rev. Fd. Sci. Nutr., 43: 19-60. https://doi.org/10.1080/10408690390826446

Franciosini, M.P., Casagrande-Proietti, P., Forte, C., Beghelli, D., Acuti, G., Zanichelli, D., dal Bosco, A., Castellini, C. and Trabalza-Marinucci, M., 2016. Effects of oregano (Origanum vulgare L.) and rosemary (Rosmarinus officinalis L.) aqueous extracts on broiler performance, immune function and intestinal microbial population. J. appl. Anim. Res., 44: 474-479. https://doi.org/10.1080/0971211 9.2015.1091322

Garcia, V., Catala-Gregori, P., Hernandez, F., Megias, M. and Madrid, J., 2007. Effect of formic acid and plant extracts on growth, nutrient digestibility, intestine mucosa morphology, and meat yield of broilers. J. appl. Poult. Res., 16: 555-562. https:// doi.org/10.3382/japr.2006-00116

Ghazanfari, S., Mohammadi, Z. and Adib Moradi, M., 2015. Effects of coriander essential oil on the performance, blood characteristics, intestinal microbiota and histological of broilers. Rev. Brasil. Ciência Avícola, 17: 419-426. https://doi. org/10.1590/1516-635X1704419-426

Gholamrezaie-Sani, L., Mohammadi, M., Jalali, S.J., Abolghasemi, S. and Roostaie-Ali-Mehr, M., 2013. Extract and leaf powder effect of Artemisia annua on performance, cellular and humoral immunity in broilers. Iranian J. Vet. Res., 14: 15-20.

Hajlaoui, H., Mighri, H., Noumi, E., Snoussi, M., 
Trabelsi, N., Ksouri, R. and Bakhrouf, A., 2010. Chemical composition and biological activities of Tunisian Cuminum cyminum L. essential oil: A high effectiveness against Vibrio spp. strains. Fd. chem. Toxicol., 48: 2186-2192. https://doi.org/10.1016/j. fct.2010.05.044

Helander, I.M., Alakomi, H.L., Latva-Kala, K., MattilaSandholm, T., Pol, I., Smid, E.J., Gorris, L.G. and von Wright, A., 1998. Characterization of the action of selected essential oil components on Gramnegative bacteria. J. Agric. Fd. Chem., 46: 35903595. https://doi.org/10.1021/jf980154m

Iacobellis, N.S., Lo Cantore, P., Capasso, F. and Senatore, F., 2005. Antibacterial activity of Cuminum cyminum L. and Carum carvi L. essential oils. J. Agric. Fd. Chem., 53: 57-61. https://doi. org/10.1021/jf0487351

Jafari, R., Ghorbanpoor, M. and Hoshmand, D.S., 2009. Study on immunomodulatory activity of dietary garlic in chickens vaccinated against avian influenza virus (subtype H9N2). Int. J. Poult. Sci., 8: 401403. https://doi.org/10.3923/ijps.2009.401.403

Jimoh, A., Ibitoye, E., Dabai, Y. and Garba, S., 2013. In vivo antimicrobial potentials of garlic against Clostridium perfringens and its promotant effects on performance of broiler chickens. Pak. J. biol. Sci., 16: 1978-1984. https://doi.org/10.3923/ pjbs.2013.1978.1984

Kapelański, W., Grajewska, S., Bocian, M., Dybała, J., Jankowiak, H. and Wiśniewska, J., 2004. Changes in blood biochemical indicators during fattening of the high-lean pigs. Anim. Sci. Pap. Rep., 22: 443449.

Kliseviciute, V., Gruzauskas, R., Grashorn, M.A., Raceviciute-Stupeliene, A., Sasyte, V., Svirmickas, G.J. and Bliznikas, S., 2014. Effect of different supplementation levels of whole Triticale grown in Lithuania to broiler diets on performance and parameters of functioning of the digestive tract. Eur. Poult. Sci., 78: 1-13.

Lukanov, H., Genchev, A. and Ribarski, S., 2015. Effect of feed supplementation with garlic power on meat productivity and meat quality traits of classic ross 308 male hybrid chickens. Trakia J. Sci., 13: 66-67. https://doi.org/10.15547/tjs.2015.01.009

Mageed, M.A.A.E., Mansour, A.F., El Massry, K.F., Ramadan, M.M., Shaheen, M.S. and Shaaban, H., 2012. Effect of microwaves on essential oils of coriander and cumin seeds and on their antioxidant and antimicrobial activities. J. Essen. Oil Bearing Pl., 15: 614-627. https://doi.org/10.1080/097206 0X.2012.10644096
Manzanilla, E., Perez, J., Martin, M., Kamel, C., Baucells, F. and Gasa, J., 2004. Effect of plant extracts and formic acid on the intestinal equilibrium of earlyweaned pigs. J. Anim. Sci., 82: 3210-3218. https:// doi.org/10.2527/2004.82113210x

Maxwell, M., Spence, S., Robertson, G. and Mitchell, M., 1990. Haematological and morphological responses of broiler chicks to hypoxia. Avian Pathol., 19: 2340. https://doi.org/10.1080/03079459008418653

Mehrabi, Z., Firouzbakhsh, F., Jafarpour, A., 2012. Effects of dietary supplementation of synbiotic on growth performance, serum biochemical parameters and carcass composition in rainbow trout (Oncorhynchus mykiss) fingerlings. J. Anim. Physiol. Anim. Nutr, 96: 474-481. https://doi. org/10.1111/j.1439-0396.2011.01167.x

Milan, K.M., Dholakia, H., Tiku, P.K. and Vishveshwaraiah, P., 2008. Enhancement of digestive enzymatic activity by cumin (Cuminum cyminum L.) and role of spent cumin as a bionutrient. Fd. Chem., 110: 678-683. https://doi. org/10.1016/j.foodchem.2008.02.062

Miles, R., Butcher, G., Henry, P. and Littell, R., 2006. Effect of antibiotic growth promoters on broiler performance, intestinal growth parameters, and quantitative morphology. Poult. Sci., 85: 476-485. https://doi.org/10.1093/ps/85.3.476

Numan, M., Zahoor, M.A., Khan, H.A. and Siddique, M., 2005. Serologic status of Newcastle disease in broilers and layers in Faisalabad and surrounding districts. Pak. Vet. J., 25: 55-58.

Oleforuh-Okoleh, V.U., Ndofor-Foleng, H.M., Olorunleke, S.O. and Uguru, J.O., 2015. Evaluation of growth performance, haematological and serum biochemical response of broiler chickens to aqueous extract of ginger and garlic. J. agric. Sci., 7: 167173. https://doi.org/10.5539/jas.v7n4p167

Peinado, M.J., Ruiz, R., Echávarri, A. and Rubio, L.A., 2012. Garlic derivative propyl propane thiosulfonate is effective against broiler enteropathogens in vivo. Poult. Sci., 91: 2148-2157. https://doi.org/10.3382/ ps.2012-02280

Platel, K. and Srinivasan, K., 1996. Influence of dietary spices or their active principles on digestive enzymes of small intestinal mucosa in rats. Int. J. Fd. Sci. Nutr., 47: 55-59. https://doi. org/10.3109/09637489609028561

Pourali, M., Mirghelenj, S.A. and Kermanshahi, H., 2010. Effect of garlic powder on productive performance and immune response of broiler chickens challenged with newcastle disiease virus. Glob. Vet., 4: 616-621. 
Saha, M., Chowdhury, S., Hossain, M., Islam, M. and Roy, B., 2013. Effect of a water soluble organic additive on growth performances, hematological parameters and cost effectiveness in broiler production. Progr. Agric., 21: 73-82. https://doi. org/10.3329/pa.v21i1-2.16754

Sharifi, S.D., Khorsandi, S.H., Khadem, A.A., Salehi, A. and Moslehi, H., 2013. The effect of four medicinal plants on the performance, blood biochemical traits and ileal microflora of broiler chicks. Vet. Arhiv., 83: $69-80$.

Sohail, M.U., Hume, M.E., Byrd, J.A., Nisbet, D.J., Ijaz, A., Sohail, A., Shabbir, M.Z. and Rehman, H., 2012. Effect of supplementation of prebiotic mannan-oligosaccharides and probiotic mixture on growth performance of broilers subjected to chronic heat stress. Poult. Sci., 91: 2235-2240. https://doi. org/10.3382/ps.2012-02182

Tollba, A., Shabaan, S. and Abdel-Mageed, M., 2010. Effects of using aromatic herbal extract and blended with organic acids on productive and physiological performance of poultry 2-the growth during cold winter stress. Anim. Prod. Inst. Giza, 1: 229-248.

Venkatesh, V., Sharma, J. and Kamal, R., 2002. A comparative study of effect of alcoholic extracts of Sapindus emarginatus, Terminalia belerica, Cuminum cyminum and Allium cepa on reproductive organs of male albino rats. Asian $J$. exp. Sci., 16: 51-63.

Wagner, D. and Thomas, O., 1978. Influence of diets containing rye or pectin on the intestinal flora of chicks. Poult. Sci., 57: 971-975. https://doi. org/10.3382/ps.0570971

Walsh, S.E., Maillard, J.Y., Russell, A., Catrenich, C., Charbonneau, D. and Bartolo, R., 2003. Activity and mechanisms of action of selected biocidal agents on Gram-positive and negative bacteria. J. appl. Microbiol., 94: 240-247. https://doi. org/10.1046/j.1365-2672.2003.01825.x

Wati, T., Ghosh, T.K., Syed, B. and Haldar, S., 2015. Comparative efficacy of a phytogenic feed additive and an antibiotic growth promoter on production performance, caecal microbial population and humoral immune response of broiler chickens inoculated with enteric pathogens. Anim. Nutr., 1: 213-219. https://doi.org/10.1016/j. aninu.2015.08.003

Yamauchi, K., Kamisoyama, H. and Isshiki, Y., 1996. Effects of fasting and refeeding on structures of the intestinal villi and epithelial cells in White Leghorn hens. Br. Poult. Sci., 37: 909-921. https:// doi.org/10.1080/00071669608417922

Yasar, S., Namik, D., Fatih, G., Gokcimen, A. and Selcuk, K., 2011. Effects of inclusion of aeriel dried parts of some herbs in broiler diets. J. Anim. Pl. Sci., 21: 465-476.

Yeung, H., 1985. Handbook of China herbs and formulas, Vol. I. Institute of China Medicine, Los Angeles, USA. 